\title{
TRĄDZIK POSPOLITY - ETIOLOGIA, KLASYFIKACJA, LECZENIE
}

\section{ACNE VULGARIS - AETIOLOGY, CLASSIFICATION, TREATMENT}

\author{
Zakład Biochemii i Żywienia Człowieka Pomorskiego Uniwersytetu Medycznego w Szczecinie \\ ul. Broniewskiego 24, 71-460 Szczecin \\ Kierownik: prof. dr hab. n. med. Ewa Stachowska \\ ${ }^{1}$ Absolwentka Wydziału Nauk o Zdrowiu Pomorskiego Uniwersytetu Medycznego w Szczecinie \\ ul. Żołnierska 48, 71-210 Szczecin
}

\begin{abstract}
Summary
A spotless skin is a rarity. Both women and men have different problems related to the complexion. One of the most common problems is acne, which affects an increasing number of people of all ages. Seborrhea skin areas rich in sebaceous glands, the formation of comedones, inflammation, and scars are characteristic for this disease.

The aim of the study was to discuss the causes of acne vulgaris, methods of treatment, and proper care of the skin affected by this problem.
\end{abstract}

K e y w or d s: acne - characteristic - skin care.

\section{Streszczenie}

Nieskazitelna cera należy do rzadkości. Zarówno u kobiet, jak i u mężczyzn występują różne problemy związane z cerą. Jedną z najczęstszych dolegliwości jest trądzik pospolity, który dotyka coraz większą liczbę ludzi w różnym wieku. Charakterystyczny dla tej choroby jest łojotok obszarów skóry bogatych w gruczoły łojowe, tworzenie się zaskórników, krostek zapalnych, grudek i blizn.

Celem pracy było omówienie przyczyn występowania trądziku pospolitego, sposobów leczenia i właściwej pielęgnacji skóry dotkniętej tym problemem.

H a s ł a: trądzik - charakterystyka - pielęgnacja cery.

\section{Epidemiologia, etiologia i etiopatogeneza trądziku pospolitego}

Trądzik pospolity (Acne vulgaris) jest jedną z najstarszych i najczęściej występujących chorób skóry. Trądzik występował już u starożytnych Egipcjan, Greków i Rzymian. Opisywali ją Arystoteles i Pliniusz [1]. Jest to schorzenie przewlekłe, szeroko rozpowszechnione, o podłożu wieloczynnikowym. Stanowi duży problem terapeutyczny, psychologiczny i społeczny [2]. Według Braun-Falco $i$ wsp. trądzik to choroba występująca w okolicach bogatych w gruczoły łojowe, która charakteryzuje się łojotokiem, tworzeniem zaskórników, krostek zapalnych, grudek i blizn [3]. Adamski i Kaszuba opisali trądzik jako przewlekłą zapalną chorobę gruczołów łojowych i ujść mieszków włosowych charakteryzującą się występowaniem wykwitów niezapalnych i zapalanych [4], natomiast Czernielewski zdefiniował Acne vulgaris jako stan zapalny aparatu gruczołu łojowego i mieszka włosowego o przewlekłym przebiegu [1].

Występowanie trądziku pospolitego uznawane jest powszechnie za bardzo częste zjawisko dotykające niemal 100\% populacji [5]. Dotyczy głównie okolic łojotokowych, w 99\% przypadków występuje na twarzy. Trądzik jest chorobą występującą już w młodym wieku, wywierającą negatywny wpływ na aspekt emocjonalny i socjalny życia. Ocenia się, że choroba ta dotyczy $80 \%$ młodzieży i może być przyczyną pojawienia się stresu, depresji i lęku $[6,7]$. Największa zapadalność przypada na okres dojrzewania, niemniej schorzenie to może się rozwijać zarówno przed okresem pokwitania, jak i utrzymywać się w wieku dorosłym [1]. 
Kobiety i mężczyźni zapadają na trądzik z równą częstotliwością, jednakże cięższe postacie występują u mężczyzn [3]. Według Czernielewskiego trądzik występuje częściej u chłopców niż u dziewcząt [1]. Pierwsze objawy trądziku u dziewcząt występują 1-2 lata wcześniej niż u chłopców. Goodman podaje, że na tę dermatozę zapada większość 16-17-letnich chłopców (95-100\%) i dziewcząt (83-85\%) [8]. Najczęściej obserwuje się łagodną postać schorzenia (w ok. $85 \%$ przypadków), natomiast ciężka postać dotyczy 15\% przypadków [9]. Szczyt zachorowań przypada na 14.-17. r.ż. u kobiet i 16.-19. r.ż. u mężczyzn [4, 10].

Acne vulgaris jest chorobą wieloczynnikową, na rozwój której wpływa wiele czynników zarówno zewnętrznych, jak i wewnętrznych [5, 6]. Należą do nich: uwarunkowania genetyczne, wytwarzanie łoju, aktywność hormonów, obecność bakterii i właściwości mieszków łojowych. Rola czynników immunologicznych w przypadku trądziku jest drugorzędna.

Pierwszym wykrywalnym objawem trądziku jest nadmierne wytwarzanie i gromadzenie się korneocytów w dystalnej części kanalika. Zrogowaciałe komórki nie złuszczają się, lecz gromadzą, co skutkuje powstaniem zaskórnika. Zaskórniki są wynikiem proliferacji mieszków i hiperkeratozy retencyjnej. Szybki strumień łoju rozpuszcza płaszcz lipidowy w mieszku i obniża poziomy cholesterolu, ceramidów i kwasu linolowego, co z kolei zaburza proces rogowacenia. Poza tym zaburzone rogowacenie doprowadza do zwiększonej przepuszczalności ściany mieszka, ułatwiając dostęp płynom i komórkom zapalnym, co sprzyja szybszej proliferacji Propionibacterium acnes. W ten sposób powstaje zaskórnik - pierwotny wykwit trądzikowy [4]. Tendencja do trądziku na pewno jest wrodzona, jednak sposób dziedziczenia nie został dokładnie określony. Sugeruje to dziedziczenie wieloczynnikowe. Prawdopodobieństwo wystąpienia schorzenia u dziecka, którego oboje rodziców chorowało na trądzik, wynosi $>50 \%$ [3]. W badaniach epidemiologicznych wykazano, że schorzenie było obecne u jednego lub obojga rodziców 45\% chłopców, którzy cierpieli na trądzik i tylko u 8\% chłopców, u których rodziców nie występowały kliniczne cechy trądziku [7].

Gruczoły łojowe i łój pełnią również istotną rolę w powstawaniu trądziku. Największe gruczoły łojowe występują najgęściej na twarzy, karku, górnej części tułowia [7]. Wszyscy chorzy na trądzik wytwarzają nadmierne ilości łoju, na skutek czego powstają wykwity. Dzięki zastosowaniu odpowiedniego leczenia i zahamowaniu wydzielania łoju zmiany trądzikowe ustępują. Łój w gruczołach oraz przewodach łojowych jest jałowy i nie zawiera wolnych kwasów tłuszczowych. Mikrośrodowisko w lejku sprzyja wzrostowi Propionibacterium acnes i Staphylococcus epidermidis. Obie bakterie są częścią prawidłowej flory skóry twarzy, lecz w razie proliferacji przyczyniają się do powstawania trądziku.

Głównym składnikiem w etiologii trądziku jest wzrost i inwazja Propionibacterium acnes. Lipazy tych bakterii rozszczepiają di- i triglicerydy, uwalniając wolne kwasy tłuszczowe. U chorych na trądzik te właśnie wolne kwasy tłuszczowe stanowią ok. 20\% lipidów na powierzchni skóry [3]. Przyczyniają się one do powstawania zaskórników, grudek, guzków, a także do występowania w późniejszym czasie blizn.

W każdym mieszku łojowym są obecne liczne bakterie i grzyby. Z grzybów, występuje głównie Malassezia furfur, jednak nie odgrywa roli w powstawaniu trądziku. W środkowym odcinku lejka można znaleźć Staphylococcus epidermidis i inne ziarenkowce. Głębiej w mieszku dominują względne beztlenowce z rodzaju Propionibacterium. Wyróżnia się trzy gatunki: Propionibacterium acnes, Propionibacterium granulosom i najrzadziej występujący Propionibacterium parvum. Ponieważ bakterie te wytwarzają porfiryny, mieszki z dużą ich ilością fluoryzują w kolorze koralowoczerwonym w świetle lampy Wooda [3].

Przed okresem pokwitania gruczoły łojowe są małe i niezdolne do przekształcania się w zmiany trądzikowe. W okresie pokwitania wzrost gruczołów łojowych jest stymulowany głównie przez androgeny, jak również przez inne hormony jajników i nadnerczy, co doprowadza do zwiększonego wydzielania łoju. Kiedy ujście takiego gruczołu zostanie zatkane przez zrogowaciałe komórki naskórka, powstanie zaskórnik. U obu płci poziomy fizjologiczne androgenów są dostatecznie wysokie, aby zapewnić niemal maksymalną aktywność gruczołów łojowych. Badania immunologiczne nie ujawniają pierwotnego tła immunologicznego u chorych na trądzik. Chorzy wykazują podwyższoną reaktywność na Propionibacterium acnes, na co wskazuje podwyższony poziom IgA i silniej zaznaczona reakcja w punktowych testach skórnych [3].

\section{Klasyfikacja trądziku}

Klasyfikacja choroby jest wieloczynnikowa i trudna do zdefiniowania. Kliniczne postacie trądziku można podzielić w zależności np. od nasilenia występujących zmian czy od czynników wywołujących wykwity [1]. Braun-Falco $i$ wsp. [3] rozróżniają trądzik zaskórnikowy, grudkowo-krostkowy i skupiony. Wolska dodatkowo definiuje trądzik bliznowaty, trądzik piorunujący oraz trądzik noworodków i niemowląt [10]. Krasowska wymienia trądzik zwyczajny, trądzik guzkowo-torbielowy (o ostrym przebiegu z objawami ogólnymi), trądzik niemowlęcy oraz trądzik prowokowany, występujący po okresie pokwitania [7].

W pracy posłużono się podziałem dokonanym przez Adamskiego i Kaszubę [11]. Autorzy podzielili trądzik na: łagodny (zaskórnikowy, grudkowy i krostkowy), umiarkowany (guzkowy i grudkowo-krostkowy), ciężki (guzkowy, ropowiczy, skupiony, bliznowaty, piorunujący, odwrócony) $\mathrm{i}$ inne postacie trądziku, w tym wywołany (zawodowy, polekowy i kosmetyczny) oraz samouszkadzający. Uwzględniając charakter zmian morfologicznych, podzielono trądzik na: młodzieńczy, ropowiczy, guzkowo-torbielowaty, skupiony, bliznowcowy, piorunujący i odwrócony [11]. Ponadto, w piśmiennictwie spotyka się jeszcze określenia takie, jak: trądzik steroidowy, mechaniczny, przed- czy pomiesiączkowy. 


\section{Charakterystyka podstawowych typów trądziku}

Trądzik zaskórnikowy, czyli trądzik młodzieńczy (Acne juvenilis), zazwyczaj dotyczy okolicy twarzy, obejmując nos, czoło i brodę. W obrazie występują liczne zaskórniki otwarte lub zamknięte o rozmiarach 1-3 mm. Zaskórniki otwarte charakteryzują się tym, że ujścia gruczołów mieszków łojowych są widoczne, o ciemnym zabarwieniu, wypełnione na powierzchni utlenioną keratyną [3]. W zaskórnikach zamkniętych ujścia gruczołów mieszków łojowych są niewidoczne. Większość pacjentów cierpi na łojotok. Trądzik zaskórnikowy pojawia się w okresie dojrzewania u młodych osób i zwykle zanika samoistnie po kilku latach. Zaskórniki pojawiają się na skutek nadmiernego wydzielania łoju, a także pod wpływem obecności bakterii. To jedna z łagodniejszych odmian trądziku, która jest zwykle łatwa do leczenia i ustępuje bez postawienia blizn.

Trądzik krostkowy stanowi jedną z odmian trądziku młodzieńczego. Typowym i najbardziej dokuczliwym objawem jest występowanie krost. Ich powstanie na skórze zapowiadają niewielkie zaczerwienienia lub twarde, bolesne krosty i guzki. Mogą się one przekształcać w ropne wypryski, na skutek czego pojawią się stany zapalne skóry, a w końcowym efekcie blizny i przebarwienia [3].

$\mathrm{W}$ trądziku grudkowo-krostkowym dominuje proces zapalny. Poza zaskórnikami pojawiają się kilkumilimetrowe wykwity o charakterze wyniosłych czerwonych grudek oraz krostki podobnej wielkości. W przeciwieństwie do krost, grudki ustępują bez pozostawienia blizn na skórze. Wykwitami może być zajęta twarz, a także klatka piersiowa i plecy, ponadto mogą także występować stwardnienia [3].

W trądziku ropowiczym (Acne phlegmonosa) na twarzy występują typowe zaskórniki, krosty i grudki oraz zmiany ropne w postaci torbieli, które są następstwem stanu zapalnego i ucisku. Jest to ciężka odmiana trądziku, w której po wygojeniu pozostają blizny [11].

Trądzik skupiony (Acne conglobata) to odmiana trądziku, który występuje głównie u mężczyzn. Charakteryzuje się występowaniem nacieków i torbieli ropnych z pozostawieniem przyrosłych blizn. W trądziku skupionym może być zajęta twarz, ale także okolice pachowe, pachwinowe i pośladki [12].

W trądziku bliznowatym, bliznowcowym (Acne keloidea), bliznowce tworzą się w obrębie wykwitów trądzikowych. Często występuje wraz z trądzikiem ropowiczym lub skupionym. W takiej sytuacji przebieg choroby jest bardzo ciężki, zmiany zapalne ustępują z pozostawieniem blizn i bliznowców [11]. Widoczne są wyraźne twarde guzy o podłużnym lub nieregularnym kształcie.

Trądzik piorunujący (Acne fluminans) jest bardzo ciężką postacią trądziku pospolitego, jednak występuje rzadko i dotyczy wyłącznie chłopców ok. 15. r.ż. Często jest następstwem nieskutecznego leczenia trądziku skupionego. Prawdopodobną przyczyną jego wystąpienia jest aktywacja układu immunologicznego. W tym trądziku zajęta jest nie tylko skóra. Zmianom trądzikowym towarzyszą takie objawy, jak wzrost temperatury ciała, bóle stawowo-mięśniowe, osłabienie [4, 13]. W wynikach badań laboratoryjnych obserwuje się wysoki poziom OB i leukocytozę [14].

Oprócz pierwotnych typów trądziku wyróżnia się jeszcze trądzik wywołany. Różni się od wcześniej omówionych rodzajów trądziku tym, że czynnik wywołujący jest z reguły znany, a objawy ustępują w przypadku jego wyeliminowania. Poniżej opisano rodzaje trądziku wywołanego.

Trądzik zawodowy (Acne professionalis) występuje u osób, które są stale narażone na oddziaływanie pewnych substancji chemicznych, m.in. związków chloru, olejów mineralnych, smarów, ropy naftowej, przetworów smołowych, smarów [15]. Występuje on także u osób pracujących w silnie zapylonych i zadymionych pomieszczeniach (np. pyłem węglowym, krzemionkowym, szklarskim, drzewnym, metalowym, czy murarskim). Objawy widoczne są głównie na przedramionach, tułowiu, w okolicach narządów płciowych, po zewnętrznych stronach podudzi [15].

Trądzik polekowy występuje po przyjmowaniu sterydów, leków wydzielających się przez gruczoły łojowe, np. witamina $\mathrm{B}_{12}$, jod, barbiturany, które działają drażniąco i powodują wzrost wydzielania łoju [1].

Trądzik kosmetyczny jest wywoływany przez długotrwały kontakt skóry z niektórymi substancjami chemicznymi, które są zawarte w kosmetykach kolorowych (najczęściej w pudrach, podkładach, różach i korektorach). Produkt kosmetyczny gromadzi się w gruczole łojowym, a wydzielany łój nie ma możliwości ujścia na zewnątrz. Wówczas w wyniku zablokowania ujść gruczołów łojowych powstają zmiany trądzikowe. Objawami tego rodzaju trądziku są grudki, krostki i zaskórniki, lecz nie występują stany zapalne. Aby się pozbyć wykwitów obejmujących skórę na policzkach, brodzie i czole wystarczy odstawić kosmetyki, które powodują występowanie trądziku [3]. Ten typ trądziku rozwija się przez kilka tygodni lub miesięcy i, jeśli się nie odstawi kosmetyków, może utrzymywać się przez długi czas.

Trądzik niemowlęcy (Acne neonatorum) to postać występująca rzadko. Jest skutkiem wpływu hormonów matki lub miejscowego działania trądzikotwórczego olejków stosowanych do pielęgnacji skóry niemowlęcia [7]. Zmiany występują jedynie w obrębie twarzy i najczęściej ustępują samoistnie w okresie kilkumiesięcznym.

Trądzik martwiczy (Acne rodens) również występuje stosunkowo rzadko. Jest powiązany z trądzikiem bliznowaciejącym. Może pojawić się zarówno u kobiet, jak i u mężczyzn. Objawy najczęściej pojawiają się na skórze owłosionej głowy i początkowo przypominają trądzik pospolity. Występują liczne pierwotne wykwity trądzikowe oraz grudki, torbiele ropne i krostki. Wszystkie zmiany, jakie miały miejsce, ulegają zejściu. Może dojść do ich martwicy, która bywa rozległa. W efekcie końcowym powstaje blizna, która jest wciągnięta i nierówna. Jej wielkość może być zróżnicowana w zależności od zmian, w obrębie których 
powstała [3]. Trądzik mechaniczny wywołany jest uciskiem okolicy bogatej w gruczoły łojotokowe i potowe z obecnością zaskórników [3].

Na szczególną uwagę zasługuje trądzik samouszkadzający, który występuje u młodych, chwiejnych emocjonalnie osób. Pojawia się w wyniku mechanicznego usuwania wykwitów trądzikowych. Zmiany są wyciskane lub rozdrapywane, wskutek czego powstają zmiany zapalne, nadżerki i owrzodzenia. Po ustąpieniu trądziku pozostają blizny, przebarwienia i odbarwienia, które są trudne do usunięcia [11].

Trądzik wiosenny (Acne aestivalis), tzw. trądzik Majorka, jest następstwem ekspozycji na wysoką temperaturę, w związku z czym częściej pojawia się latem lub wiosną. Ten rodzaj trądziku może być również spowodowany stosowaniem oleistych fotoprotektorów. Najczęściej cierpią na niego osoby przebywające w tropikalnym klimacie lub wykonujące pracę w warunkach wysokiej temperatury. Wyraźne objawy to grudki przymieszkowe występujące w miejscach narażonych na silne promieniowanie słoneczne. W tej postaci trądziku krosty i zaskórniki nie występują [12].

\section{Metody leczenia}

Postępowanie lecznicze uzależnione jest od postaci trądziku i zróżnicowanego stopnia nasilenia zmian chorobowych. Ogólnym celem leczenia jest zapobieganie występowaniu nadmiernego rogowacenia skóry, zahamowanie rozwoju bakterii Propionibacterium acnes oraz zmniejszenie łojotoku, gdyż każdy z tych czynników przyczynia się do występowania i nasilania objawów choroby.

$\mathrm{W}$ walce $\mathrm{z}$ trądzikiem może być zastosowane leczenie miejscowe lub ogólne. Leczenie miejscowe stosowane jest przede wszystkim w łagodnych oraz umiarkowanych postaciach trądziku. Większość pacjentów można leczyć jedynie preparatami miejscowymi, jednak nie zawsze jest to skuteczne [16]. Bardzo często metody stosowane w leczeniu miejscowym są elementem uzupełniającym podczas leczenia ogólnego, dzięki czemu efekty są lepsze. Do najczęściej stosowanych preparatów o działaniu miejscowym należą: antybiotyki, nadtlenek benzoilu, kwas azelainowy oraz pochodne witaminy A. Są to związki zazwyczaj bardzo dobrze tolerowane i rzadko wywołują skutki uboczne [16]. Do najczęściej stosowanych antybiotyków należą makrolidy, np. erytromycyna czy klindamycyna. Wykazują one działanie przeciwbakteryjne, ograniczają stan zapalny i redukują ilość wolnych kwasów tłuszczowych. Leki te są najskuteczniejsze w połączeniu z nadtlenkiem benzoilu, gdyż stosowane oddzielnie powodują antybiotykooporność [17]. Nadtlenek benzoilu wykazuje silne działanie przeciwbakteryjne, ponadto działa keratolitycznie, powodując znaczną redukcję liczby zaskórników [10]. Wywiera również efekt przeciwzapalny i hamuje wzmożone wydzielanie łoju. Preparaty zawierające nadtlenek benzoilu powinny być stosowane jako leki pierwszego rzutu w leczeniu łagodnych i umiarkowanych postaci trądziku pospolitego [15]. W zależności od stężenia preparatu mogą występować objawy niepożądane, takie jak wysuszenie i złuszczanie skóry oraz jej odczyn zapalny.

Często wykorzystywany jest także kwas azelainowy, który po raz pierwszy został dopuszczony do stosowania w Stanach Zjednoczonych pod koniec lat 90. XX w. [17]. Działa na główne czynniki etiopatogenetyczne trądziku pospolitego, czyli wzmożoną sekrecję łoju o nieprawidłowym składzie, przerost gruczołów łojowych i nadmierne rogowacenie ujść mieszków włosowych. Wpływa również bakteriostatycznie, hamując wzrost bakterii wokół mieszków włosowych i w ujściach gruczołów łojowych. Ma także właściwości przeciwzapalne, lekko złuszczające oraz komedolityczne, redukując liczbę zmian niezapalnych [12]. Wykorzystywany jest przy łagodnych i średnio nasilonych postaciach trądziku. Przy długotrwałym stosowaniu związek ten hamuje tendencje do tworzenia blizn. Ponadto wykazano, że jest cennym preparatem w leczeniu przebarwień pozapalnych [9]. Ponieważ kwas azelainowy ma wielokierunkowe działanie, nie ma potrzeby łączyć go z innymi preparatami miejscowymi. Podobnie jak nadtlenek benzoilu, nie wywołuje zjawiska antybiotykooporności [16].

Ważną grupę leków w terapii Acne vulgaris stanowią też miejscowo stosowane retinoidy. Pochodne witaminy A hamują tworzenie mikrozaskórników, zmniejszają liczbę dojrzałych zaskórników oraz stanów zapalnych, a także normalizują proces dojrzewania i złuszczania mieszków włosowych [13]. W leczeniu trądziku najczęściej wykorzystywane są: tretinoina, adapalen i tazaroten. Leczenie ogólne stosowane jest w umiarkowanych oraz ciężkich postaciach trądziku. Ten sposób zaleca się również u osób, u których na skutek występowania trądziku powstają blizny, bliznowce i przebarwienia pozapalne. W terapii ogólnej wykorzystuje się antybiotyki, retinoidy i antyandrogeny, które mają działanie przeciwzapalne i hamują wzrost bakterii $[9,18,19]$.

Antybiotykami najczęściej stosowanymi w leczeniu ogólnym są: tetracyklina, erytromycyna, kotrimoksazol oraz klindamycyna. Działają one przeciwbakteryjnie i silnie przeciwzapalnie, a tetracyklina również przeciwłojotokowo [17]. Erytromycyna wykazuje skuteczność porównywalną z teracykliną, lecz częściej pojawia się oporność na ten antybiotyk. Doustna antybiotykoterapia powinna być stosowana przez minimum 6-7 miesięcy. Po 6 miesiącach poprawa jest widoczna u 80-90\% pacjentów [16].

Szeroko stosowane jest też leczenie hormonalne. Dotyczy to głównie kobiet, u których nieskuteczna jest terapia konwencjonalna, a ponadto z różnych przyczyn nie może być stosowana terapia retinoidami [17]. Wskazane jest także u kobiet z trądzikiem o wczesnym początku, opornym na leczenie antybiotykami. Zaleca się preparaty zawierające progestageny pozbawione aktywności androgenowej, dzięki czemu zostanie obniżona produkcja łoju [14]. Ważne jest, aby leczenie hormonalne trwało 6-12 miesięcy. Poprawa może być widoczna już po 4-6 tyg. stosowania terapii. Do leków stosowanych najczęściej zalicza się spironolakton oraz octan cyproteronu w połączeniu $\mathrm{z}$ etinyloestradiolem. 
Nierzadko do leków hormonalnych dołącza się leczenie doustne izotretinoiną, co zwiększa skuteczność terapii. Izotretinoina należy do retinoidów stosowanych w leczeniu ogólnym ciężkich i bardzo ciężkich postaci trądziku [12]. Lek ten wpływa na wszystkie mechanizmy patogenezy choroby, a więc zmniejsza wydzielanie łoju, działa przeciwbakteryjnie, przeciwzapalnie, przeciwzaskórnikowo, powoduje inwolucję gruczołów łojowych [20,21]. Leczenie tym związkiem stosuje się w zaawansowanych postaciach trądziku, ale także w przypadku częstych nawrotów choroby, w wyniku braku reakcji na długie stosowanie terapii konwencjonalnej [9]. Izotretinoina jest także skuteczna u osób z występującym bliznowaceniem podczas zaburzeń psychicznych wynikających z choroby oraz w przypadku silnego łojotoku. Podczas leczenia izotretinoiną nie jest wymagane stosowanie innych preparatów miejscowych [21]. Ze względu na działanie teratogenne, kobietom zaleca się stosowanie antykoncepcji [18].

\section{Pielęgnacja cery trądzikowej}

W przypadku łagodnych postaci trądziku oraz po leczeniu dermatologicznym umiarkowanych i ciężkich odmian choroby istotna jest właściwa pielęgnacja skóry zarówno w domu, jak i w gabinecie kosmetycznym. Zaleca się stosowanie kosmetyków, które są przeznaczone do skóry tłustej lub trądzikowej [22]. Powinny mieć postać żeli lub lekkiej emulsji typu O/W [23]. Preparaty te pomagają likwidować nadmiar wydzielanego łoju, nie zatykają porów, przywracają skórze odpowiednie $\mathrm{pH}$, a także zapobiegają stanom zapalnym [24]. W przypadku przesuszania się skóry zaleca się używanie kosmetyków nawilżających bez zawartości thuszczu [25]. Odpowiednia pielęgnacja wpływa na poprawę mikrokrążenia, dotlenienie i oczyszczenie skóry, a także pomaga odbudować naturalną barierę ochronną. W skład preparatów przeznaczonych do pielęgnacji cery trądzikowej powinny wchodzić składniki o działaniu przeciwzapalnym, przeciwbakteryjnym, ściągającym, matującym oraz łagodzącym, kojącym i nawilżającym [22, 23, 26]. Jest wiele składników aktywnych o takim działaniu, jednak na szczególną uwagę zasługuje cynk (działa wysuszająco, ściągająco, absorbuje nadmiar sebum, przyspiesza gojenie się skóry), czarne błoto (działa silnie antyseptycznie, wysuszająco, odkażająco, ściągająco i przeciwzapalne), siarka (działa oczyszczająco, wysuszająco, złuszczająco, przeciwzapalnie, antybakteryjnie, reguluje pracę gruczołów łojowych, zmniejsza wydzielanie sebum, matuje skórę), fiołek trójbarwny (działa łagodząco i ściągająco), olejek z drzewa herbacianego (działa na Propionibacterium acnes, normalizuje pracę gruczołów łojowych, dezynfekuje, nie powoduje nadmiernego wysuszenia i podrażnień) [23].

W handlu dostępnych jest bardzo wiele kosmetyków przeznaczonych do pielęgnacji cery trądzikowej. Jednak wyniki badań przeprowadzonych przez Macioł $i$ wsp. dowodzą, że niestety nie wszystkie kosmetyki drogeryjne zawierają w swym składzie składniki aktywne wspomagające leczenie trądziku [22]. Ponadto zdecydowana ich większość zawiera składniki ,problematyczne”, np. konserwanty oraz związki zapachowe o znanym potencjale uczulającym i drażniącym.

Domowa pielęgnacja skóry nie zawsze przynosi oczekiwane efekty, szczególnie w sytuacji silnych zmian chorobowych. Niemniej nie można jej pomijać, gdyż w przypadku występowania trądziku codzienna higiena jest bardzo ważna.

Należy także pamiętać o korzystaniu ze skutecznych zabiegów kosmetycznych i/lub dermatologicznych w wyspecjalizowanych gabinetach. Terapia powinna być dobierana indywidualnie z uwzględnieniem stopienia nasilenia choroby [27]. Przy cerach trądzikowych polecane są różne bezbolesne zabiegi pielęgnacyjne. Jednym z najbardziej znanych zabiegów wykonywanych w gabinetach kosmetycznych jest oczyszczanie manualne cery. Pomaga pozbyć się zaskórników i grudek, zwęża pory skóry. Należy pamiętać, że nie wolno wykonywać oczyszczania u osób ze zmianami ropnymi i zapalnymi [28]. Mikrodermabrazja to pielęgnacyjny zabieg kosmetyczny stosowany od połowy lat 80 . XX w. Polega na złuszczaniu kolejnych warstw naskórka, co pozwala na dokładne oczyszczenie cery, zmniejsza poszerzone pory i rozświetla skórę [12]. Z kolei peeling kawitacyjny pozwala dokładnie usunąc nadmiar sebum, złuszcza zrogowaciały naskórek, likwiduje zanieczyszczenia, a także bakterie, które wpływają na postawanie trądziku [28]. Zastosowanie znalazły również peelingi chemiczne [12]. Procedura ich stosowania polega na nałożeniu na skórę odpowiednio dobranej mieszaniny związków chemicznych o określonym, dobranym do cery stężeniu. Najczęściej stosowany jest kwas glikolowy otrzymywany z trzciny cukrowej, a także kwas mlekowy, azelainowy, migdałowy, kwasy owocowe oraz kwas salicylowy [13]. Peelingi chemiczne, oprócz działania złuszczającego i przeciwzapalnego, działają również komedolityczne, czyli rozpuszczają zaskórniki, zmniejszają nadmiar wydzielanego sebum oraz zwężają pory [16]. W leczeniu blizn potrądzikowych stosowana jest laseroterapia [12]. Wykorzystywane są lasery (np. $\mathrm{CO}_{2}$ ), których światło powoduje szybkie gojenie się istniejących zmian oraz zapobiega powstawaniu nowych. Ich działanie polega na tym, że precyzyjnie dobrana wiązka światła wnika w głąb skóry i działając na gruczoły łojowe, ogranicza produkcję sebum. Ponadto światło lasera ma właściwości przeciwzapalne, odkażające i obkurczające pory [27]. Fototerapia znalazła natomiast zastosowanie w leczeniu ciężkich i opornych na leczenie postaci trądziku. Wykazuje silne działanie przeciwzapalne, przeciwbakteryjne oraz złuszczające [27]. Zabiegiem o silnym działaniu bakteriobójczym i bakteriostatycznym jest darsonwalizacja (mikroprądy D'arsonvala). Zabieg ten polega na masażu szklaną elektrodą (pelotą) wypełnioną gazem szlachetnym pola zabiegowego. Powoduje to wyładowania elektryczne na powierzchni skóry i uwolnienie ozonu, który ma dobroczynne działanie na skórę. Efektem jest redukcja zmian trądzikowych, obkurczenie porów, hamowanie wydzielania 
sebum, pobudzenie procesów regeneracji skóry, stymulacja złuszczania martwego naskórka. W pielęgnacji cery wykorzystuje się też jonoforezę. Zabieg ten polega na wprowadzeniu do tkanek jonów leków za pomocą prądu stałego. Do cer trądzikowych można zastosować kwas askorbinowy, wodorowęglan sodowy, siarczan miedzi, salicylan sodu [28].

Jednym w czynników determinujących stan skóry jest sposób odżywiania. W profilaktyce trądziku nie należy zapominać o przestrzeganiu prawidłowo zbilansowanej diety [29], która powinna być bogata w białko, a uboga w tłuszcze i węglowodany [12]. Uwzględnić trzeba podaż substancji o działaniu antyoksydacyjnym, w tym witamin oraz makro- i mikroelementów. Wykazują one łagodzący wpływ na objawy trądziku oraz korzystny wpływ na wygląd skóry [30]. Warto także unikać produktów i potraw, które mogą przyczyniać się do zaostrzenia objawów trądziku [29]. Chorzy nie powinni spożywać alkoholu, ostrych przypraw, orzechów czy czekolady [12].

Trądzik pospolity stanowi duży problem medyczny oraz społeczny i dotyczy coraz większej liczby osób, nie tylko w okresie pokwitania. Znajomość przyczyn jego powstawania, czynników sprzyjających, jak również świadomość właściwej pielęgnacji skóry i istotnego wpływu diety mogą przyczynić się do zmniejszenia skali problemu związanego z występowaniem trądziku pospolitego.

\section{Piśmiennictwo}

1. Czernielewski A.: Zarys chorób skóry, błony śluzowej, jamy ustnej i wenerycznych. PZWL, Warszawa 1982, 302-307.

2. Mojs E.: Choroby skóry w ujęciu psychosomatycznym. Now Lek. 2010, 6, 483-486.

3. Braun-Falco O., Plewig G., Wolff H.H., Burdgdorf W.H.C.: Dermatologia. Wyd. Czelej, Lublin 2004, 993-1002.

4. Adamski Z., Kaszuba A.: Dermatologia dla kosmetologów. Wyd. Elsevier Urban \& Partner, Wrocław 2010, 54-58.

5. Langner A., Ambroziak M., Stapór W: Trądzik pospolity-podstawowe zasady leczenia. Przew Lek. 2000, 4, 78-82.

6. Bergler-Czop B., Brzezińska-Wcisło L.: Nawroty zmian chorobowych u pacjentów z rozpoznaniem trądziku, leczonych Izotretinoiną i innymi metodami. Wiad Lek. 2006, 59 (3-4), 152-157.

7. Krasowska D.: Etiopatogeneza i obraz kliniczny trądziku pospolitego. Derm Estet. 2006, 2, 67-71.
8. Goodman G.J.: Patofizjologia blizn potrądzikowych - krótki opis mechanizmu ich powstawania. Derm Estet. 2002, 1, 22-28.

9. Postępy dermatologii. Ed. J. Bowszyc. Suplement II do tomu XIII. Poznań 1996, 4, 15.

10. Wolska H.: Dermatologia w praktyce. PZWL, Warszawa 2009, 144-148.

11. Adamski Z., Kaszuba A.: Dermatologia. Poradnik lekarza praktyka. Wyd. Czelej, Lublin 2012, 101-107.

12. Trądzik. Phytomedica Polska. http://phytomedica.pl/pdf/tradzik.pdf. (12.02.2014).

13. Nowicka D.: Choroby łojotokowe skóry. Wyd. Kosmed, Wrocław 2011, 11-26.

14. Biegalska J., Żaba R.: Trądzik pospolity. Przew Lek. 2004, 6, 36-60.

15. Leczenie chorób skóry. Ed. A. Kaszuba. Wyd. Elsevier Urban \& Partner. Wrocław 2009, 302-307.

16. Kaszuba A.: Trądzik pospolity: leczenie miejscowe preparatami prostymi w terapii naprzemiennej. Derm Prakt. 2010, 4, 9-17.

17. Trądzik. Diagnostyka i leczenie. Ed. D. Krasowska. Wyd. Czelej, Lublin 2009, 115-170.

18. Raszeja-Kotelba B.: Trądzik pospolity - obraz kliniczny, rozpoznanie i leczenie. Lek Rodz. 2003, 55-59.

19. Placek W., Romańska-Gocka K., Grzanka A.: Leczenie miejscowe trądziku. Przegl Dermatol. 2011, 98, 442-448.

20. Kaszuba A., Kisiel K., Uczniak S.: Izotretinoina doustna w leczeniu różnych odmian klinicznych trądziku pospolitego. Forum Med Rodz. 2009, 4, 257-265.

21. Brzeziński P.: Niskie dawki izotretynoiny w terapii trądziku zwykłego. Derm Prakt. 2012, 3, 51-53.

22. Maciot D., Kordus K., Śpiewak R.: Kosmetyki do cery trądzikowej dostępne w drogeriach: analiza deklarowanych składników aktywnych oraz substancji potencjalnie niebezpiecznych. Estetol Med Kosmetol. 2012, 3, 83-88.

23. Michalak M.: Składniki aktywne kontra trądzik. Cabines Polska. 2012 54, 34-39.

24. Karpińska-Mrowiecka M.: Postępowanie pielęgnacyjne w trądziku. Dermatologia i Uroda. Jesień-Zima. 2011, 3-6.

25. Dudley A., Mitchell T.: Trądzik. Jak leczyć? Jak ukryć? Wyd. KDC, Warszawa 2008, 131-133.

26. Tazbir M.: Ocena skuteczności i tolerancji preparatów kosmetycznych przeznaczonych do pielęgnacji skóry trądzikowej. Derm Estet. 2011, $3,167-174$.

27. Kaszuba A.: Wspomagające i zabiegowe metody leczenia trądziku pospolitego oraz zmian potrądzikowych. Derm Estet. 2005, 4, 194-197.

28. Cieślewicz M.: Zabiegi łagodzące objawy trądziku. Cabines Polska. 2012, 5, 34-37.

29. Omeljaniuk W.J., Socha K., Markowska D.: Sposób odżywiania studentek Wyższej Szkoły Kosmetologii i Ochrony Zdrowia w Białymstoku w przypadku trądziku skóry. Bromat Chem Toksykol. 2011, 44, 3, 484-490.

30. Bojarowicz H., Woźniak B.: Wielonienasycone kwasy tłuszczowe oraz ich wpływ na skórę. Probl Hig Epidemiol. 2008, 4, 471-475. 